\title{
New records of Sea Spiders (Arthropoda: Pycnogonida) for continental Portugal and notes on species distribution
}

\author{
Patricia Esquete ${ }^{1,2^{*}}$, Marcos Rubal ${ }^{2,3,4}$, Puri Veiga $a^{3,4}$ and Jesús Troncoso 2,5
}

\begin{abstract}
A sampling effort carried out in the Northern coast of Portugal revealed the presence of two species of sea spiders that are recorded for the first time in Portugal: Anoplodactylus angulatus and Ammothella longioculata. While A. angulatus is widespread along the North East Atlantic coast, A. longioculata is recorded for the first time outside of the Mediterranean Sea. Eight species were recorded in this survey, increasing the pycnogonid species list of Portugal to twenty-four. A species list of the Pycnogonids of continental Portugal including references and distribution is provided.
\end{abstract}

Keywords: Anoplodactylus angulatus, Ammothella longioculata, Iberian Peninsula, Portugal, Atlantic

\section{Introduction}

Pycnogonids or sea spiders are an exclusively marine group of arthropods that includes 1340 species (Bamber et al., 2015). Their phylogenetic position has been the subject of debate for many years, and they are currently considered to be a sister group of the rest of the Chelicerata (Regier et al, 2010; Andrew, 2011), although their phylogeny is not clearly resolved.

By comparison with other areas, the Pycnogonida of the Iberian Peninsula have been intensively studied (see Soler-Membrives \& Munilla, 2015). Nevertheless, faunal studies focused on pycnogonids in Portuguese waters are scarce in the literature; most of the available data come from wider studies on benthic community studies where pycnogonids are rarely found in high numbers.

The first attempt to document pycnogonid records and studies of the Portuguese fauna was by Nogueira (1956) who listed 16 species (13 coastal, 3 abyssal). In her synopsis Nogueira (1967) corrected the list, recognizing 19 species, and Stock (1978) described a new species of Nymphon from abyssal depth off Portugal increasing the pycnogonid species to 20. Recently, Munilla León and Soler-Membrives (2014) in their

\footnotetext{
* Correspondence: pesquete@ua.pt

${ }^{1}$ Center of Environmental and Marine Studies, Universidade de Aveiro,

Aveiro, Portugal

${ }^{2}$ Departamento de Ecoloxía e Bioloxía Animal, Universidade de Vigo, Vigo,

Spain

Full list of author information is available at the end of the article
}

monograph of the Pycnogonida of the Iberian Peninsula and Balearic Islands added two more species from a revision of material performed by Munilla in Lisbon Museu Bocage, totalling 22 species.

In this paper, all records available for Portuguese waters are collated adding new information gathered from sampling on the northern coast, including ecological remarks.

\section{Materials and methods}

Three granitic rocky shores were sampled along the Portuguese north coast between June and July 2010

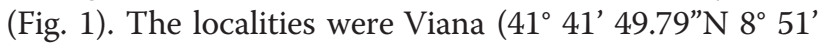
$\left.10.52^{\prime \prime W}\right)$, Foz $\left(41^{\circ} 09^{\prime} 15.55^{\prime \prime} \mathrm{N} 8^{\circ} 40^{\prime} 50.46^{\prime \prime W}\right)$ and Aguda $\left(41^{\circ} 02^{\prime} 43.22^{\prime \prime} \mathrm{N} 08^{\circ} 39^{\prime} 10.31^{\prime \prime} \mathrm{W}\right)$. The survey area presents a semidiurnal tidal regime, with the largest spring tides about $4.0 \mathrm{~m}$. The exposed coastline is dominated by swells from the north- west (73\%) with about $19 \%$ of swells coming from the west. Swell direction plays a key role in controlling nearshore circulation responsible for a continuous interchange between surf zone and offshore waters. The mean wave height varies widely between seasons, with typical wave heights during the spring-summer months being between 1 and $3 \mathrm{~m}$. Most storms occur during autumn-winter months when waves often exceed $7 \mathrm{~m}$ in height (Dias et al., 2002). A more detailed description of the study area including 


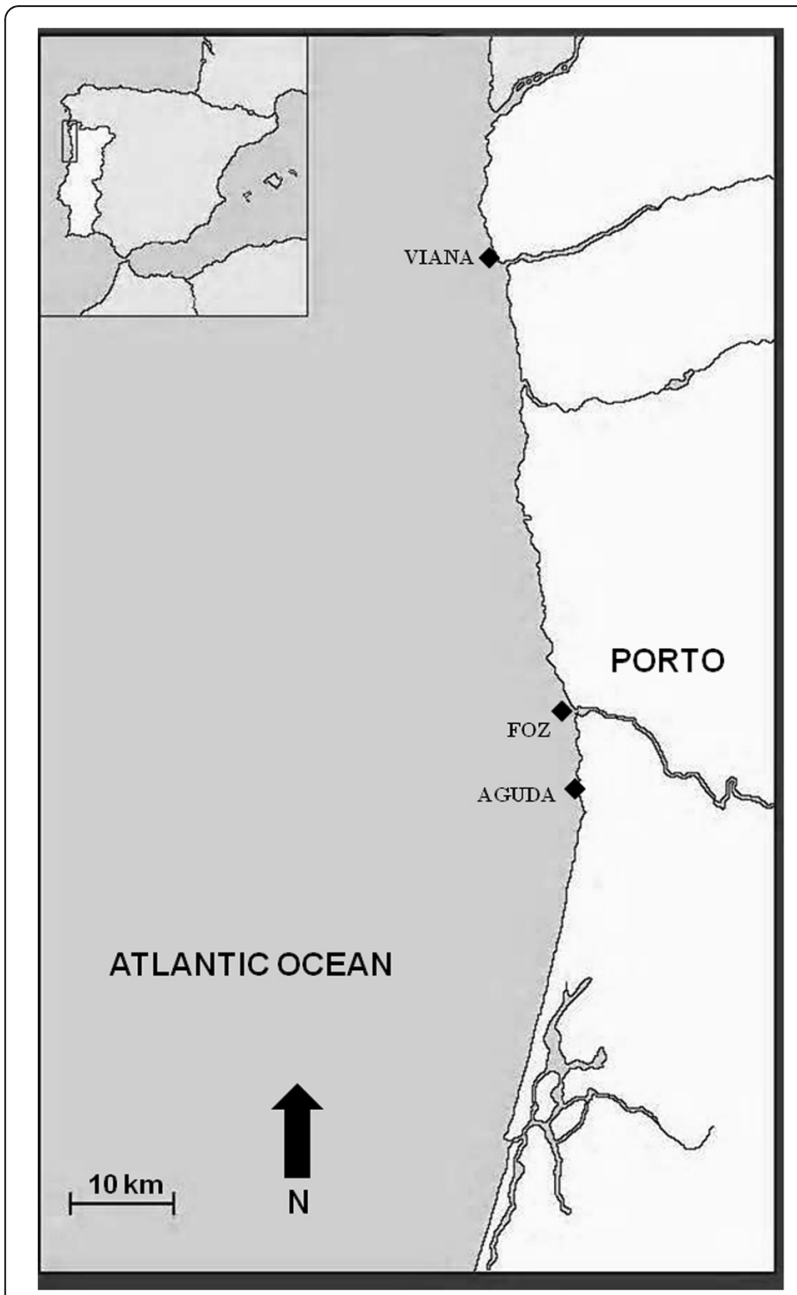

Fig. 1 Map of the Portuguese coast indicating the location of the 3 sampled shores

patterns of surface water temperature, upwelling etc. can be found in Rubal et al. (2013).

Sampling was done at low tide level. The dominant algae associated with pycnogonid collections were: Viana: assemblages dominated by Corallina officinalis, Lithophyllum spp. and Mastocarpus stellatus; Foz: assemblages dominated by Chondracanthus acicularis, Codium tomentosum and Osmundea pinnatifida and Aguda: assemblages dominated by Ulva spp., Chondracanthus acicularis and Corallina officinalis. For a detailed list of macroalga species in each shore see Veiga et al. (2013a).

In each site, 15 samples of $20 \times 20 \mathrm{~cm}$ (an approximate area of $0.6 \mathrm{~m}^{2}$ ) were scraped and all fauna and algae collected in a labelled plastic bag. Samples were pooled in the field and fixed in $4 \%$ neutralized formaldehyde solution. Each sample was washed over a $0.5 \mathrm{~mm}$ sieve in the laboratory and pycnogonids were sorted from the macroalgae under a dissecting microscope at 30x magnification.
Specimens from each site were stored in ethanol (70 \%) pending taxonomic study.

In this study we provide a complete list of Pycnogonida present along continental Portugal compiled from existing literature (Table 1). Due to significant environmental gradients along the Portuguese coast, we have divided it in three regions similar to previous studies (e.g. Veiga et al., 2013b) based on oceanographic, geological and biological criteria described by Rubal et al. (2013): North Portugal from the Minho estuary to Aveiro, central Portugal from Aveiro to Sines and south Portugal from Sines to the estuary of the Guadiana river. The southern coastline of the Algarve was not considered due to the lack of pycnogonid records.

Part of the specimens were donated to the Museo Natural de Ciencias Naturales de Madrid (MNCN). The rest remains in the collection of the Laboratory of Marine Animals Adaptations (ADAM) of the University of Vigo (Spain). Classification and nomenclature follows that of Bamber (2010). This report covers the coastal and off-shore waters of continental Portugal only. An account of pycnogonid collections from the Açores can be found in Bamber \& Costa (2009).

\section{Results and discussion}

A total of eight pycnogonid species were found in this study (Table 1), six of which were previously known from Portuguese coasts. Ammothella longioculata (Faraggiana, 1940) and Anoplodactylus angulatus (Dohrn, 1881) represent new records increasing the number of species from continental Portuguese waters to twenty-four (Table 1).

\section{New records}

SYSTEMATICS

Family AMMOTHEIDAE Dohrn, 1881

Genus Ammothella Verrill, 1900

Ammothella longioculata (Faraggiana, 1940)

Ammothea (Ammothella) longioculata: Faraggiana, 1940

\section{Material examined}

3 specimens, MNCN 20.03/858-860 and 10 specimens, ADAM, all Foz, 41ㅇ 09' 15.55”N 8 40’ 50.46”W, 29/07/ 2010, macroalgae, intertidal, collected by M. Rubal and P. Veiga. 1 specimen, ADAM, Aguda, $41^{\circ} 02^{\prime} 43.22$ "N $08^{\circ}$ 39'10.31"W, 30/07/2010, macroalgae, intertidal, collected by M. Rubal and P. Veiga.

\section{Diagnosis}

After Bamber (2010) and Munilla León and SolerMembrives (2014): Trunk with sutures present between segments 1 and 2 and between 2 and 3. Cephalon with conspicuous anterolateral tubercles, ocular tubercle three times as tall as wide, with four eyes. Lateral processes separated, each bearing a dorsodistal, elongate, 
Table 1 List of Pycnogoid species collected in continental shores of Portugal

\begin{tabular}{|c|c|c|c|c|c|}
\hline Species & Depth & Habitat & Sites & Region & Reference \\
\hline \multicolumn{6}{|l|}{ Family Nymphonidae } \\
\hline Nymphon gracile Leach, 1814 & । & $M, P$ & $\vee(1)$ & $\mathrm{N}, \mathrm{C}, \mathrm{S}$ & Nobre, 1903 \\
\hline Nymphon macrum Wilson, 1880 & $\mathrm{~S}(78 \mathrm{~m})$ & - & nf & N & Stephensen, 1935 \\
\hline Nymphon tubiferum Stock, 1978 & $\mathrm{D}(740 \mathrm{~m})$ & MS & nf & C & Stock, 1978 \\
\hline \multicolumn{6}{|l|}{ Family Callipallenidae } \\
\hline Callipallene brevirostris (Johnston, 1837) & $\mathrm{S}$ & - & nf & - & Stock, 1952 \\
\hline Callipallene emaciata (Dohrn, 1881) & I & M & nf & C & Nogueira, 1956; Patrício et al. 2006 \\
\hline Callipallene tiberi (Dohrn, 1881) & $\mathrm{D}$ & $M, S$ & nf & $C, S$ & Nogueira, 1956 \\
\hline \multicolumn{6}{|l|}{ Family Phoxichilidiidae } \\
\hline Anoplodactylus angulatus (Dohrn, 1881) & । & M & $V(1)$ & N & This study \\
\hline Anoplodatylus oculatus Carpenter, 1905 & S, D & & nf & C & Munilla León et al. 2014 \\
\hline Anoplodactylus petiolatus (Kroyer, 1844) & I & M & $V(1)$ & $\mathrm{N}, \mathrm{C}, \mathrm{S}$ & Nogueira, 1956; Cunha et al. 1997 \\
\hline Anoplodactylus pygmaeus (Hodge, 1864) & । & M & $V(1), A(2)$ & $N, C, S$ & Nogueira, 1956; Neto et al., 2010 \\
\hline Anoplodactylus virescens (Hodge, 1864) & I, S & M & $F(1), A(3)$ & $\mathrm{N}, \mathrm{C}, \mathrm{S}$ & Nogueira, 1956; Patrício et al. 2006 \\
\hline \multicolumn{6}{|l|}{ Family Endeidae } \\
\hline Endeis spinosa (Montagu, 1808) & I & M & $\mathrm{nf}$ & $C, S$ & Nogueira, 1956 \\
\hline \multicolumn{6}{|l|}{ Family Ammotheidae } \\
\hline Achelia echinata Hodge, 1864 & I,S & M & $V(1)$ & $N, C, S$ & Nogueira, 1956 \\
\hline Achelia langi (Dohrn, 1881) & I & - & $\mathrm{nf}$ & C, S & Nogueira, 1967 \\
\hline Achelia vulgaris (Costa, 1861) & I,S & $M, S$ & nf & C, S & Nogueira, 1956 \\
\hline Ammothella longioculata (Faraggiana, 1940) & I & M & $F(13), A(1)$ & N & This study \\
\hline Cilunculus europaeus Stock, 1978 & $\mathrm{D}$ & $M, S$ & $\mathrm{nf}$ & $C$ & Munilla León et al. 2014 \\
\hline Ammothella longipes (Hodge, 1864) & I & $M, S$ & $V(1), F(1)$ & $\mathrm{N}, \mathrm{C}$ & Nogueira, 1956 \\
\hline Paranymphon spinosum Caullery, 1896 & $\mathrm{D}(750 \mathrm{~m})$ & MS & nf & S & Loman, 1912 \\
\hline Tanystylum conirostre (Dohrn, 1881) & I & - & $\mathrm{nf}$ & C, S & Nogueira, 1967 \\
\hline Tanystylum orbiculare Wilson, 1878 & I & M & $\mathrm{nf}$ & C & Nogueira, 1956 \\
\hline \multicolumn{6}{|l|}{ Family Ascorhynchidae } \\
\hline Ascorhynchus abyssi Sars, 1877 & D (1500 m) & - & $\mathrm{nf}$ & S & Bouvier, 1917 \\
\hline \multicolumn{6}{|l|}{ Family Colossendeidae } \\
\hline Colossendeis colossea Wilson, 1881 & D (2028 m) & MS & $\mathrm{nf}$ & C & Topsent, 1897 \\
\hline \multicolumn{6}{|l|}{ Family Pycnogonidae } \\
\hline Pycnogonum litorale (Strom, 1762) & । & M & $\mathrm{nf}$ & $\mathrm{N}, \mathrm{C}$ & Nobre, 1903, Azeda et al., 2013 \\
\hline
\end{tabular}

Depth: intertidal (I), subtidal (S) and deep sea (D) when available the depth was provided in meters. Habitat: macroalgae (M), sand (S), muddy sand (MS) and plankton (P). Sites where species were found in this study, Viana (V), Foz (F), Aguda (A), not found (nf) and the number of individuals. Region: North Portugal (N), central Portugal (C) and South Portugal (S). Bold references refer to works versed specifically on pycnogonids; the rest are generalist ecological works

fleshy tubercle with no seta. Abdomen with pair of dorsodistal setae, exceeding distal margin of first coxa of fourth leg. Proboscis large, fusiform. Chelifores present, reaching half of proboscis length; scape one articled, with distal plumose spines. Palps of nine articles, second longer than fourth, five distal articles subequal, ventrally setose. Ovigers with compound spines in pairs on articles 7 to 10 . Walking legs with simple spines and some plumose spines, femur shorter than tibiae, bearing cement gland opening in males via short distal tube, tarsus short, sole of propodus with three or four larger spines, auxiliary claws about half as long as the main claw.

\section{Distribution}

Mediterranean Sea and North of Portugal.

\section{Remarks}

Ammothella longioculata, described from the Ligurian Sea (Faraggiana, 1940) has been cited on ten occasions, all in the Mediterranean Sea (Koçak \& Katagan 2008 
and references therein), where it is considered endemic and is widespread from East to West in northern and western coasts (Koçak \& Katagan 2008; Munilla León and Soler-Membrives 2014). The westernmost record to date is from Chafarinas Islands in Alboran Sea (Munilla \& Nieto 1999), and the current record represents the first for A. longioculata in the Atlantic. The sea water in the North-West Atlantic coast of the Iberian Peninsula is often colder than in the Mediterranean and the hydrodynamic pressure significantly higher, so the occurrence in Northern Portugal indicates that A. longioculata tolerates a broader range of these two factors than previously thought.

In the Iberian Mediterranean, A. longioculata is found at $12 \mathrm{~m}$ depth, while in the Atlantic was found in the intertidal. This depth difference suggests habitat shift in order to maintain the temperature preferred and might indicate temperature constraints for this species. As pycnogonid species are rarely identified to species level in benthic surveys and Portugal shore is poorly sampled, it is most likely that this species it has gone unnoticed until now.

Family PHOXICHILIDIIDAE Sars, 1891

Genus Anoplodactylus Wilson, 1878

Anoplodactylus angulatus (Dohrn, 1881)

Phoxichilidium angulatum: Dohrn, 1881

\section{Material examined}

1 specimen, MNCN 20.03/861, Viana, 41 4 41' 49.79”N $8^{\circ}$ 51' 10.52 ”W, 30/07/2010, macroalgae, intertidal, collected by M. Rubal and P. Veiga.

\section{Diagnosis}

After Bamber (2010) and Munilla León and SolerMembrives (2014): Trunk compact, sutures present. Cephalon not overhanging proboscis base. Lateral processes with no tubercles, slightly separated. Ocular tubercle dome shaped, with four pigmented eyes. Proboscis with characteristic distinct angulate distal corners, with ventral basal protuberance in males. Abdomen inclined about $45^{\circ}$, reaching mid-length of the last legs first coxa. Chelifores scape straight, as long as proboscis, chela palm longer than fingers, fingers with 3-6 internal teeth. Ovigers six articled. Walking legs sparsely spinose, first coxa with two distolateral spines, coxa 2 as long as 1 and 2 together, femur with 2-6 cement pores, femur and tibia subequal in length, tarsus compact, propodus with distinct heel, bearing two large proximal and three slender distal spines, sole with no lamina, main claw about as long as sole, auxiliary claws small, lateral.

\section{Distribution}

Northeast Atlantic and Mediterranean Sea.

\section{Remarks}

Anoplodactylus angulatus has been recorded not only in the Mediterranean Sea (e. g. Arnaud, 1987; Munilla, 1988; Krapp et al., 2008; Koçak et al., 2010) but also in the British Isles (King \& Crapp 1971; Roberts, 1981) and Macaronesia (Sanchez and Munilla 1989; Bamber and Costa 2009), which indicates that the species is widespread in the area in spite of the scarcity of its records. This species is now new record for Portuguese waters.

\section{Other Pycnogonida species found in this study}

Only three of the remaining species had been previously recorded in the north of Portugal: Nymphon gracile Leach, 1814, Nymphon macrum Wilson, 1880 and Pycnogonum litorale (Strom, 1762). These were recorded by Nobre (1903), Stephensen (1935) and Nogueira (1956, 1967). On the other hand, the new records (i.e. A. longioculata and $A$. angulatus) and $N$. macrum are the only species recorded exclusively in the northern region although their broad general distribution in the North East Atlantic suggests that they might be present throughout the Portuguese coast.

Two additional species previously known from southern areas of Portugal were found in the north for the first time: Anoplodactylus pygmaeus (Hodge, 1864) and Anoplodactylus virescens (Hodge, 1864), although the latter was cited in the Northwest of Spain (Munilla, 1987; SolerMembrives \& Munilla, 2015). P. litorale, previously found at Foz by Nobre (1903) was not recorded. Azeda et al. (2013) listed this species amongst the taxa found in a monitoring survey near Lisbon, which would confirm the presence of this species in the central region.

Callipallene brevirostris (Jonhston, 1837) was listed by Stock (1952) as being recorded from the littoral zone on the Portuguese coast but the precise location has not been identified. Nogueira (1967) questioned this record and the species has not been recorded again. Nevertheless, the presence of $C$. brevirostris in northern Portugal is feasible, given the recent report in the nearby Galicia, NW Spain (Esquete et al., 2013)

Nogueira overlooked Tanystylum conirostre (Dohrn, 1881) in her first report of the pycnogonids of Portugal (1956), but amended the mistake in her synopsis (1967), although in the latter the description and drawings of Tanystylum orbiculare Wilson, 1878 and T. conirostre are confounded.

The 24 pycnogonid species recorded in Portugal (Table 1) represent about $36 \%$ of the 65 species found in the Iberian Peninsula (Munilla León and SolerMembrives 2014) and about $25 \%$ of the 84 species recorded by Bamber (2010) for the North East Atlantic. These results suggest that the pycnogonid diversity in the continental Portuguese shores is still poorly known, and an increase in the research effort will improve the information about the diversity and geographical 


\section{distribution of the Pycnogonida in the Iberian Peninsula and worldwide.}

\section{Acknowledgments}

This study was funded by the Polis Litoral Norte S.A. through the project "Estudo de caracterização da actividade pesqueira costeira e dos seus impactes nos recursos e nas comunidades marinhas do Litoral Norte" and also partially supported by the European Regional Development Fund (ERDF) through the COMPETE - Operational Competitiveness Programme and national funds through FCT - Foundation for Science and Technology, under the project "PEst-C/MAR/LA0015/2011". During this study, the first author (SFRH/BPD/94985/2013) and the third author (SFRH/BPD/81582/2011) were supported by postdoctoral grant awarded by Fundacão para a Ciência e Tecnologia (FCT, Portugal). The second author (POS-A/2012/221) was funded by a postdoctoral grant (programa posdoutoral Xunta de Galicia, Spain).

\section{Authors' contributions}

MR and PV did the sampling and sorting of the samples and drafted parts of the manuscript. PE identified the specimens and redacted the manuscript. All authors read and approved the final manuscript.

\section{Competing interests}

None of the authors have any competing interests in the manuscript.

\section{Author details}

'Center of Environmental and Marine Studies, Universidade de Aveiro, Aveiro, Portugal. ${ }^{2}$ Departamento de Ecoloxía e Bioloxía Animal, Universidade de Vigo, Vigo, Spain. ${ }^{3}$ Department of Biology, Faculty of Sciences, University of Porto, Porto, Portugal. ${ }^{4}$ CIIMAR/CIMAR, Centro Interdisciplinar de Investigação Marinha e Ambiental, Porto, Portugal. ${ }^{5}$ ECIMAT, Estación de Ciencias Marinas de Toralla, Vigo, Spain.

\section{Received: 16 March 2016 Accepted: 15 April 2016}

\section{Published online: 12 June 2016}

\section{References}

Andrew DR. A new view of insect-crustacean relationships II. Inferences from expressed sequence tags and comparisons with neural cladistics. Arthropod Struct Dev. 2011;40:289-302. http://dx.doi.org/10.1016/j.asd.2011.02.001.

Arnaud F. Les Pycnogonides (Chelicerata) de Méditerranée: distribution écologique, bathymetrique et biogéographie. Mésogée. 1987;47:37-58.

Azeda C, Sá E, Silva G, Medeiros JP, Tavares MJ, de Almeida PR, Metelo I, Costa JL, Costa MJ. Preliminary results of biological monitoring using benthic macroinfauna of the discharge areas of Lisbon drainage basins in Tagus estuary after new developments in sanitation infrastructures. J Sea Res. 2013; 83:163-72. http://dx.doi.org/10.1016/j.seares.2013.05.017.

Bamber RN. Sea-Spiders (Pycnogonida) of the North-East Atlantic: Keys and Notes for the Identification of the Species. Shrewsbury: Linnean Society of London by the Field Studies Council; 2010.

Bamber R, Costa AC. The pycnogonids (Arthropoda: Pycnogonida) of São Miguel Azores, with description of a new species of Anoplodactylus Wilson, 1878 (Phoxichilidiidae). Açoreana. 2009;6:167-82.

Bamber RN, El Nagar A, Staples D. Pycnobase: World Pycnogonida Database. http://www.marinespecies.org/pycnobase accessed 13 July 2015.

Bouvier EL. Pycnogonides provenant des campagnes scientifiques de S. A. S. Le Prince Monaco (1885-1913). Resultats des Campagnes Scientifiques de Monaco. 1917:51:1-56.

Cunha MR, Sorbe JC, Bernardes C. On the structure of the neritic suprabenthic communities from the Portuguese continental margin. Mar Ecol: Prog Ser. 1997;157:119-37. http://dx.doi.org/10.3354/meps157119.

Dias JMA, Gonzalez R, Garcia C, Diaz-del RV. Sediment distribution patterns on the Galicia-Minho continental shelf. Prog Oceanogr. 2002;52(2):215-31. http://dx.doi.org/10.1016/S0079-6611(02)00007-1.

Esquete P, Bamber RN, Moreira J, Troncoso JS. Pycnogonids (Arthropoda: Pycnogonida) in seagrass meadows: the case of O Grove inlet (NW Iberian Peninsula). Thalassas. 2013;29(1):25-33.

Faraggiana R. Pantopodi del Mare Ligure. Bollettino dei Musei di Zoologia e Anatomia Comparata di Torino. 1940;48:145-58.

King PE, Crapp GB. Littoral pycnogonids of the British Isles. Field Stud. 1971;3(3): 455-80.
Koçak C, Katagan T. First record of Ammothella longioculata (Pycnogonida: Ammotheidae) on the Cypriot coast (eastern Mediterranean). Marine Biodiversity Records. 2008;1:e85. http://dx.doi.org/10.1017/ S1755267207008755.

Koçak C, Katagan TY, Sukatar A. New records of shallow water sea spiders (Arthropoda, Pycnogonida) from Turkey. Zoology in the Middle East. 2010; 49(1):118-20. http://dx.doi.org/10.1080/09397140.2010.10638403.

Krapp F, Kocak C, Katagan T. Pycnogonida (Arthropoda) from the eastern Mediterranean Sea with description of a new species of Anoplodactylus. Zootaxa. 2008;1686:57-68.

Loman JCC. Note préliminaire sur les "Podosomata" (Pycnogonides) du Musée Océanographique de Monaco. Bulletin de l'Institut océanographique de Monaco. 1912;238:1-14.

Munilla T. Picnogónidos costeros del norte de España. Miscellania Zoológica. 1987;11:369-73.

Munilla T. Premiers Pycnogonides du dètroit de Gibraltar (Côté Ibérique). Butlletí de la Institució Catalana d'Història Natural. 1988:55:59-65.

Munilla León T, Soler-Membrives A. Fauna Ibérica. Vol. 39: Pycnogonida. Madrid: Consejo Superior de Investigaciones Científicas; 2014.

Munilla T, Nieto D. Littoral pycnogonids from the Chafarinas islands (Alboran Sea, western Mediterranean). Vie Milieu. 1999;49(2-3):155-61.

Neto JM, Teixeira H, Patrício J, Baeta A, Veríssimo H, Pinto R, Marques JC. The response of estuarine macrobenthic communities to natural-and humaninduced changes: dynamics and ecological quality. Estuar Coasts. 2010;33(6): 1327-39.

Nobre A. Subsídios para o estudo da fauna marinha do norte de Portugal. Annaes the Sciencias Naturaes. 1903:8:37-94.

Nogueira M. Pantopodos das costas de Portugal. Arquivos do Museu Bocage. 1956;27:65-105.

Nogueira M. Bases para a determinação dos Pantopodos das costas Portuguesas. Arquivos do Museu Bocage. 1967;1 (15):283-341.

Patrício J, Salas F, Pardal MÂ, Jørgensen SE, Marques JC. Ecological indicators performance during a re-colonisation field experiment and its compliance with ecosystem theories. Ecol Indic. 2006;6(1):43-57. http://dx.doi.org/10. 1016/j.ecolind.2005.08.016.

Regier JC, Shultz JW, Zwick A, Hussey A, Ball B, Wetzer R, Martin JW, Cunningham CW. Arthropod relationships revealed by phylogenomic analysis of nuclear protein-coding sequences. Nature. 2010;463(7284):1079-83. http://dx.doi.org/ 10.1038/nature08742

Roberts D. Pycnogonids from Strangford Lough, Northern Ireland. The Irish Naturalists' Journal. 1981;20(5):189-192.

Rubal M, Veiga P, Cacabelos E, Moreira J, Sousa-Pinto I. Increasing sea surface temperature and range shifts of intertidal gastropods along the Iberian Peninsula. J Sea Res. 2013;77:1-10. http://dx.doi.org/10.1016/.jseares.2012.12.003.

Sanchez E, Munilla T. Estudio ecológico de los primeros picnogónidos litorales de las Islas Canarias. Cah Biol Mar. 1989;30:49-67.

Soler-Membrives A, Munilla T. PYCNOIB: Biodiversity and Biogeography of Iberian Pycnogonids. PLoS One. 2015;10(3):e0120818. http://dx.doi.org/10.1371/ journal.pone.0120818.

Stephensen K. Pycnogonida from Norway and adjacent waters. Bergens Museum Aarbok, Naturvid Række. 1935;7:1-39.

Stock JH. Revision of the European genus Callipallene Flynn, 1929 (Pycnogonida). Beaufortia. 1952;1(13):1-14.

Stock JH. Abyssal Pycnogonida from the North-eastern Atlantic Basin, Part I. Cah Biol Mar. 1978;19:189-219.

Topsent E. Pycnogonides recueillis par le yacht 'Princesse Alice'. Bulletin de la Societé Zoologique Française. 1987;22:106-7.

Veiga P, Rubal M, Vieira R, Arenas F, Sousa-Pinto I. Spatial variability in intertidal macroalgal assemblages on the North Portuguese coast: consistence between species and functional group approaches. Helgol Mar Res. 2013a; 67(1):191-201. http://dx.doi.org/10.1007/s10152-012-0315-2.

Veiga P, Rubal M, Cacabelos E, Moreira J, Sousa-Pinto I. Abundance and fragmentation patterns of the ecosystem engineer Lithophyllum byssoides (Lamarck) Foslie along the Iberian Peninsula Atlantic coast. Conservation and management implications. J Sea Res. 2013b;46:40-6. http://dx.doi.org/10. 1016/j.seares.2013.03.016. 